\title{
COMPETITION OF Amaranthus SPECIES WITH DRY BEAN PLANTS
}

\author{
Saul Jorge Pinto de Carvalho ${ }^{1}$; Pedro Jacob Christoffoleti ${ }^{2 *}$ \\ ${ }^{1}$ USP/ESALQ - Programa de Pós-Graduação em Fitotecnia. \\ ${ }^{2}$ USP/ESALQ - Depto. de Produção Vegetal, C.P. 09 - 13418-900 - Piracicaba, SP - Brasil. \\ *Corresponding author <pjchrist@esalq.usp.br>
}

\begin{abstract}
Weeds compete with field crops mainly for water, light and nutrients, and this competition is among other factors, a function of the occurrence of weed density, and the intrinsic competitive ability of each vegetal species. The objective of this research was to evaluate the competitive ability of five weed species of the Amaranthus L. genus (A. deflexus, A. hybridus, A. retroflexus, A. spinosus and $A$. viridis) with dry bean plants (Phaseolus vulgaris L. - 'Carioca Precoce' cultivar), using the replacement series design. A fixed total density equivalent to 80 plants $\mathrm{m}^{-2}$ was used in pots of $2.8 \mathrm{~L}$ capacity varying the proportions between the species in coexistence. To install the experiment, Amaranthus seedlings were transplanted to the pots at the phenological stage of completely expanded cotyledon leaves, while the crop was seeded. A factorial scheme $(5 \times 5)$ was used to carry out the experiment, consisting of five species of Amaranthus (pigweeds) and five species proportions (beans:pigweeds): 4:0, 3:1, 2:2, 1:3 and 0:4. Randomized blocks with four replicates were installed and the experiment was repeated twice. Dry bean plants were more competitive than each one of the five Amaranthus species when the species proportion was equivalent. A. deflexus and A. viridis were the weed species which phenology were less affected by the competition with dry bean; the intraspecific competition was more damaging for dry bean plants, suggesting that the damages caused by the weeds are more related to high density of infestation than to the intrinsic competitive ability of the species.

Key words: Phaseolus vulgaris L., pigweed, competitiveness, dry mass
\end{abstract}

\section{COMPETIÇÃO DE ESPÉCIES DE Amaranthus COM PLANTAS DE FEIJOEIRO}

\begin{abstract}
RESUMO: As plantas daninhas competem com as culturas por água, luz e nutrientes, sendo que esta competição é função da densidade de ocorrência das plantas daninhas, bem como da habilidade competitiva intrínseca de cada espécie. O objetivo desta pesquisa foi avaliar a competitividade de cinco espécies de Amaranthus L. (A. deflexus, A. hybridus, A. retroflexus, A. spinosus e A. viridis) com plantas de feijoeiro (Phaseolus vulgaris L. - cultivar Carioca Precoce), por meio de experimentos em delineamentos substitutivos. A população total de quatro plantas por vaso de $2,8 \mathrm{~L}$, que equivale a uma densidade de 80 plantas $\mathrm{m}^{-2}$, foi fixada em todos os tratamentos, variando-se as proporções entre as duas espécies em convivência. Para as proporções, as parcelas receberam o transplante de plântulas de Amaranthus em estádio de folhas cotiledonares plenamente expandidas e semeadura do feijão. Utilizouse modelo de tratamentos fatorial $5 \times 5$, ou seja, cinco espécies de Amaranthus (carurus) e cinco proporções de plantas (feijão:caruru): 4:0, 3:1, 2:2, 1:3 e 0:4. O delineamento experimental utilizado foi em blocos ao acaso, com quatro repetições, sendo o experimento repetido duas vezes. A cultura do feijoeiro foi melhor competidora que todas as espécies de Amaranthus estudadas neste trabalho, quando cultivadas em proporções iguais; $A$. deflexus e $A$. viridis foram as espécies com a fenologia menos afetada pela competição com o feijoeiro; a competição intraespecífica foi a mais prejudicial ao feijoeiro, o que sugere que os danos causados pelas plantas daninhas estão mais relacionados com as altas densidades de ocorrência do que com a habilidade competitiva intrínseca das espécies.

Palavras-chave: Phaseolus vulgaris L., caruru, competitividade, massa seca
\end{abstract}

\section{INTRODUCTION}

Dry bean (Phaseolus vulgaris L.) is a shortlived cycle crop, highly sensitive to weed interference, mainly during the initial stages of its vegetative development (Cobucci, 2004). Weeds interfere in crop yield mainly competing for sunlight, water and soil nutrients; and the interference intensity for each one of these factors is difficult to be measured due to the inter relation among them, once the deficiency of one may affect the species competitiveness by the others (Fleck, 1992). Competition is the result of a relation 
between the distribution of plant limiting resources to the species in the agroecossystem, and the efficiency that each one has in using these resources to produce biomass (Rohrig \& Stutzel, 2001).

Weed infestation in dry bean fields may cause yield reductions up to $70 \%$ when not correctly managed (Arévalo \& Rozanski, 1991; Kozlowski et al., 2002). The weeds can also reduce grain quality, make the harvest difficult and host insects and pathogens that may affect negatively the crop (Christoffoleti et al., 2005). Timing of the weed control during dry bean cropping is also an important factor to be considered, and the critical period of weed interference (CPWI) is between V3 (first trifoliate leaf) and R5-R6 (flower buds - flowering) crop growth stages (Christoffoleti et al., 2005).

Weeds classified as Amaranthus L. genus (pigweeds) are found commonly infesting the dry bean fields. The high competitiveness of Amaranthus weeds may be related to the $\mathrm{C}_{4}$ cycle of carbon assimilation, the speed and timing of germination, the species speed of growth, and the high density of infestation (Anderson \& Nielsen, 1996; Itulya et al., 1997; Kissmann \& Groth, 1999; Aguyoh \& Masiunas, 2003).

The aim of this research was to evaluate the competitiveness of five weed species of the Amaranthus genus (A. deflexus L., A. hybridus L., A. retroflexus L., $A$. spinosus L. and $A$. viridis L.) with dry bean plants ('Carioca Precoce' cultivar), through experiments with the replacement series design.

\section{MATERIAL AND METHODS}

The research was conducted in a greenhouse at Piracicaba, State of São Paulo - SP, Brazil (22\%41' $\mathrm{S}, 47^{\circ} 41^{\prime} \mathrm{W}$ and $560 \mathrm{~m}$ of altitude), from August to December, 2005, repeating it two times. The selected weed species were: A. deflexus, A. hybridus, $A$. retroflexus, $A$. spinosus and $A$. viridis. The propagules of $A$. hybridus, $A$. spinosus and $A$. viridis were acquired commercially, while $A$. deflexus and $A$. retroflexus propagules were collected from plants in intestate areas found in the region of Piracicaba - SP (A. deflexus) and in agricultural areas of Miguelópolis ( $20^{\circ} 10^{\prime} \mathrm{S}, 48^{\circ} 01^{\prime} \mathrm{W}$ and $510 \mathrm{~m}$ of altitude) and Guará $\left(20^{\circ} 25^{\prime} \mathrm{S}, 47^{\circ} 49^{\prime} \mathrm{W}\right.$ and $573 \mathrm{~m}$ of altitude) - SP ( $A$. retroflexus). Seeds of $A$. hybridus, A. retroflexus and A. viridis; and fruits of $A$. deflexus and $A$. spinosus were used according to the main form of the species dispersal.

Seeds or fruits of the five Amaranthus species germinated in plastic boxes, $2 \mathrm{~L}$ capacity, filled with a commercial substrate (Pinus bark + turf + vermiculite). The species were seeded in a total interval of five days: $A$. deflexus was the first species sown; after one day, A. spinosus; after three days, A. retroflexus; and after five days, $A$. hybridus and $A$. viridis. This methodology was adopted to exclude the effects of the species germination speed on the competition, obtaining seedlings with the same phenological stage for all the species.

The emergence was synchronized and transplantations were made for all species simultaneously on September $5^{\text {th }}$ (first seeding date) and October $29^{\text {th }}$ (second seeding date). At this moment, the seedlings presented the phenological stage of completely expanded cotyledon leaves, i.e., stage 10 (Hess et al., 1997). The dry bean was seeded right after pigweed transplantation to each plot.

The plots consisted of $2.8 \mathrm{~L}$ plastic pots, filled with a mixture of commercial substrate and vermiculite, in a 2:1 proportion. Three days before transplantation, the pots were fertilized (mg per pot): $\mathrm{N}$ at 600; $\mathrm{P}_{2} \mathrm{O}_{5}$ at $600 ; \mathrm{K}_{2} \mathrm{O}$ at $800 ; \mathrm{Ca}$ at $44 ; \mathrm{S}$ at $160 ; \mathrm{Mg}$ at $16 ; \mathrm{Zn}$ at 2; $\mathrm{B}$ at 2; $\mathrm{Fe}$ at 4 and $\mathrm{Mn}$ at 1.2. The pots were irrigated when necessary in order to keep the soil water content close to the field capacity.

Initially for each pot two pigweed spare seedlings were transplanted and for the dry bean, two seeds were planted knowing that only one plant should remain, with the objective of ensuring the final population in each treatment. The plants were thinned out on September $14^{\text {th }}$ (first seeding date) and November $6^{\text {th }}$ (second seeding date). Four true leaves and completely expanded cotyledon leaves were the phenological stages identified for pigweeds and dry beans, respectively.

The treatments were based on a replacement series design for studies of competition in mixed populations of plants according to the methodology described by Cousens (1991). The design is based on keeping constant the total plant density per plot, and changing proportion between the species (Harper, 1977). The populations of the isolated species are also included in the experiment and are called monocultures. The main objective of this kind of experiment has been to determine the total yield of the mixtures compared to the monoculture yield (Radosevich, 1987; Roush et al., 1989; Radosevich \& Roush, 1990). The replacement series have been used mainly to determine the best competitor of two species or biotypes and to understand how they interact with each other (Cousens, 1991).

A population of four plants was kept per pot, distributed homogenously in the pot, which is equivalent to 80 plants $\mathrm{m}^{-2}$. The treatments consisted of different dry bean and pigweed plant proportions. The proportions were (dry bean: pigweed): 4:0, 3:1, 2:2, $1: 3$ and 0:4. These proportions correspond to 100,75 , 50,25 and $0 \%$ of dry bean plants, and the inverse of 
pigweed plants, i.e., 0, 25, 50, 75 and 100\%, respectively, which also identify the expected production of the species, if competitively equivalent. Five replacement series design were installed, one for each of the Amaranthus species, all in mixture with dry beans of the cultivar 'Carioca Precoce' (determinate growth).

The experimental design consisted of randomized blocks with four replicates. The treatment scheme was a complete factorial $5 \times 5$, with five species proportions and five pigweed species. At the end of the dry bean vegetative cycle, apex meristeme differentiation to flower buds (30 days after seeding), pigweed phenological stages were evaluated for all the proportions and species, using the phenological scale described by Hess et al. (1997). These evaluations were conducted on October $5^{\text {th }}$ (first seeding date) and November $30^{\text {th }}$ (second seeding date). Subsequently, shoot dry biomass of both species were measured (dried at $70^{\circ} \mathrm{C}$, during $72 \mathrm{~h}$ ).

Data were analyzed through the application of the ' $F$ ' test on variance analyses, followed by Tukey's test $(\alpha=0.05)$, on the significant qualitative factors. After that, data were submitted to conventional analyses for replacement series experiments (Radosevich, 1987). For each proportion, the observed relative yields were calculated by dividing the observed production in the different proportions by the mean yield of the monoculture (Wit \& Berg, 1965; McGilchrist \& Trenbath, 1971; Harper, 1977; Christoffoleti, 1992). The expected and observed productions were compared using the standard mean error of the observed production.

\section{RESULTS AND DISCUSSION}

The application of the ' $F$ ' test on variance analyses did not detect any differences between the two seeding dates, so that the results were analyzed together. Pigweed species did not influence the dry bean phenology, once all dry bean plants were at the flower bud stage at the end of the experiment. No pigweed species effect were statistically observed on dry bean shoot dry biomass, indicating that all the pigweed species have the same competitive ability in relation to dry bean plants. Likewise, the interaction species-proportion was not significant, although the isolated effect of proportion was detected (Table 1).

The tests of multiple comparisons were rejected for the pigweed shoot dry mass because the species have naturally different growth habits and the simple comparison of this variable may not correspond to reality (Carvalho, 2006). In this case, the phenological development of the pigweeds presents a clearer comparison of the conditions obtained in this experiment.

The maintenance of monoculture in the pots (100\% pigweeds) benefited the phenological development of these species indicating that the interespecific competition was more significant for these species in Table 2. In this growth condition, even the less developed species (A. retroflexus) reached the 51 stage (Hess et al., 1997) which corresponds to the presence of visible inflorescence.

Intraspecific competition may be highly intense, because similar individuals in a population have the same needs for quantity, quality and seasonality of the growth factors. On the other side, the interespecific competition is more important when the levels of the ambient resources are not enough for both species (Ricklefs, 1997). Plants are considered efficient competitors when they use quickly a certain resource or when they are able to keep the development even at low levels of these resources in the environment (Radosevich, 1996).

Table 1 - Dry bean (cv. 'Carioca Precoce') shoot dry biomass at the phenological stage of flower buds (30 days after seeding) submitted to different competitive proportions of five Amaranthus species (pigweeds), at the total density of 80 plants $\mathrm{m}^{-2}$. Piracicaba, SP, Brazil, 2005.

\begin{tabular}{|c|c|c|c|c|c|c|}
\hline \multirow{2}{*}{$\begin{array}{l}\text { Dry bean } \\
\text { Proportion }\end{array}$} & \multicolumn{6}{|c|}{ Amaranthus species } \\
\hline & A. deflexus & A. hybridus & A. retroflexus & A. spinosus & A. viridis & Mean $^{1}$ \\
\hline \multicolumn{7}{|c|}{-.--g per pot } \\
\hline 100 & 9.97 & 10.03 & 9.97 & 10.22 & 10.16 & $10.07 \mathrm{a}$ \\
\hline 75 & 7.95 & 10.77 & 8.78 & 8.01 & 8.36 & $8.77 \mathrm{~b}$ \\
\hline 50 & 7.28 & 6.93 & 6.75 & 5.80 & 7.30 & $6.80 \mathrm{c}$ \\
\hline 25 & 4.39 & 3.81 & 3.98 & 3.39 & 4.20 & $3.95 \mathrm{~d}$ \\
\hline \multirow[t]{2}{*}{ Mean } & 7.40 & 7.88 & 7.37 & 6.85 & 7.51 & --- \\
\hline & $F_{(s p)}=1.64^{n s}$ & $x$ prop) $=1.36^{\mathrm{ns}}$ & rop) $=107.09 * *$ & $\mathrm{SD}_{\text {(prop) }}=0.95$ & $(\%)=20.56$ & \\
\hline
\end{tabular}

\footnotetext{
**Significant at 'F' test with $1 \%$ of probability; ${ }^{\text {ns }}$ Not significant; ${ }^{1}$ Means followed by the same letter, in the column, are not different according to the Tukey's test $(P>0.05)$.
} 
Table 2 - Phenological stages (Hess et al., 1997) of the Amaranthus species (pigweeds), 30 days after experiment installation, submitted to different competitive proportions of dry bean plants (cv. Carioca Precoce), for 80 plants $\mathrm{m}^{-2}$ density. Piracicaba, SP, Brazil, 2005.

\begin{tabular}{lccccc}
\hline \multirow{2}{*}{$\begin{array}{l}\text { Pigweed } \\
\text { Proportions }\end{array}$} & \multicolumn{5}{c}{ Amaranthus species phenological stages } \\
\cline { 2 - 6 }$\%$ & A. deflexus & A. hybridus & A. retroflexus & A. spinosus & A. viridis \\
\hline 25 & 63 & 34 & 34 & 30 & 59 \\
50 & 61 & 38 & 30 & 38 & 63 \\
75 & 65 & 51 & 50 & 51 & 63 \\
100 & 69 & 59 & 51 & 61 & 65 \\
\hline
\end{tabular}

The reduction of the pigweed proportion in the pots resulted in a poorer performance of these species, with clear interespecific differences, $A$. deflexus and $A$. viridis being those with the best development at low specific proportion $(25 \%)$. Therefore, Amaranthus interespecific competition with the dry bean plants is more significant for the development of the weeds than the intraspecific competition (Table 2), mainly for A. hybridus, A. retroflexus and A. spinosus. These results are in agreement with Christoffoleti \& Victoria Filho (1996) that used the replacement series to evaluate the interespecific competition of corn (Zea mays L.) with $A$. retroflexus, in 400 plants $\mathrm{m}^{-2}$ density. Corn was much more efficient for competition than the pigweed, and the intraspecific competition was more important for the crop than the interespecific one. The opposite was true for the pigweed, i.e., the interespecific competition was the most important for this species.

Considering just one crop species, the competitive capacity is, up to a certain point, related to the variety. The best characteristics of the competitive varieties are: fast germination, fast emergence and initial growth, intense recruitment of environmental resources and high capacity of sunlight interception. These abilities reduce the use of the essential resources by the weeds (Pitelli \& Pitelli, 2004).

All the Amaranthus species were worse competitors than the dry bean crop as demonstrated by the bars of the standard mean error (Figure 1). A. deflexus presented negative difference between the observed and the expected production, mainly in the proportions of 25 and $50 \%$ (Figure 1-A), although its phenology was little affected (Table 2).

The results related to the proportion of $50 \%$ between the species are considered the critical point for a replacement series experiment analyses, since it clearly shows the best competitor, because the species are in equivalent proportion. Comparing the observed yield of dry beans with the expected yield - bars of the standard mean error - A. hybridus and $A$. retroflexus were weak competitors to the crop, once crop yield in all proportions was higher than the expected (Figures 1-B and C). A. spinosus was the pigweed species that most damaged the observed shoot mass yield of the dry bean plants, which was kept with little differences to the expected shoot mass yield (Figure 1-D).

A. viridis presented medium levels of competitiveness once at the same time the observed production was slightly different of the expected tendency; the dry bean observed production was slightly superior to the expected condition (Figure 1-E), and the effects of competition on the phenology of this Amaranthus species was little pronounced (Table 2). Although, in general, dry bean plants were better competitors for the available growth resources than all the Amaranthus species, presenting always productions superior to the expectative when the proportion in the pots was smaller than $100 \%$ (Figure 1-F).

Data of the common-bean competition with Brachiaria plantaginea (alexandergrass) is also available in the literature (Passini et al., 2003). In this case, common-bean was also a better competitor than the alexandergrass and the intraspecific competition was more intense than the interespecific one, i.e., the competitive effect among common-bean plants was higher than the competitive effect of alexandergrass over common-bean. Plants of common-bean were observed to emerge first and grow faster than alexandergrass, presenting higher plants and greater leaf area which could have contributed for its better competitive performance.

In some occasions, two species which have similar requirements for natural resources can differ in their responses (Harper, 1977). The more aggressive species contributes more than the expected to the total yield, while the other contributes less than expected. Therefore, one curve is concave and the other is convex, indicating that the interaction between these species is for the same natural resources, but one species is more efficient in using them (Passini et al., 2003). Dry bean probably captured the resources with more efficiency than the Amaranthus species and so 
A

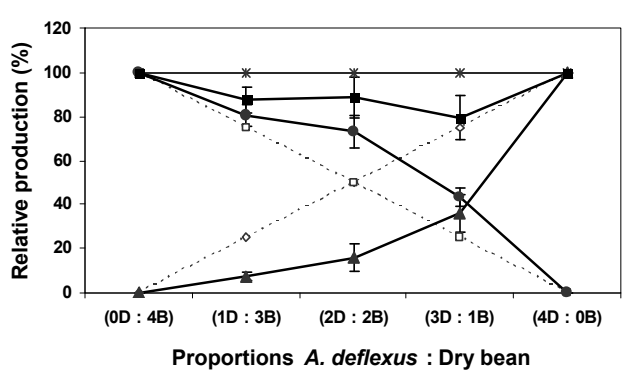

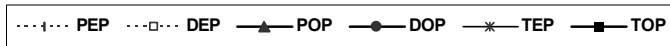

C

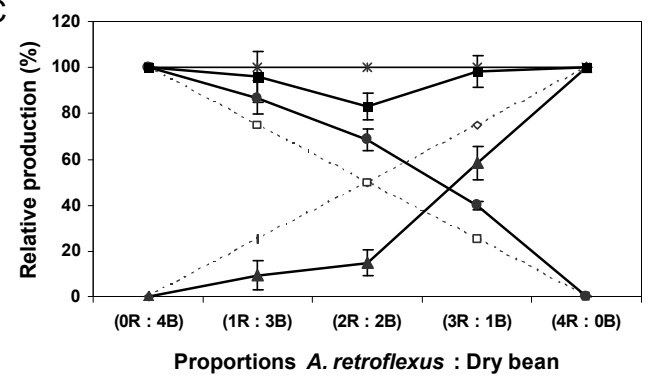

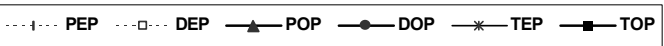

$\mathrm{E}$

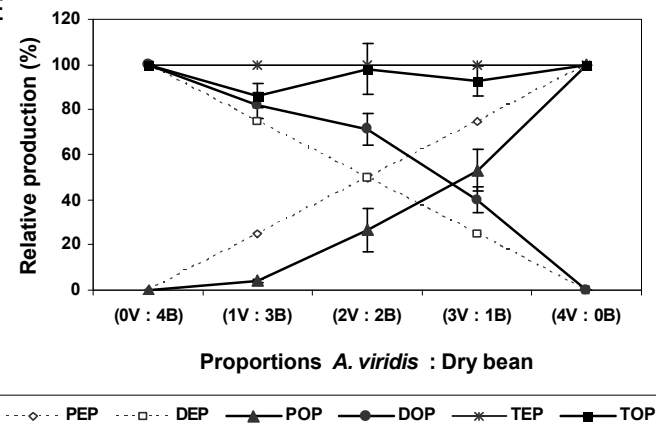

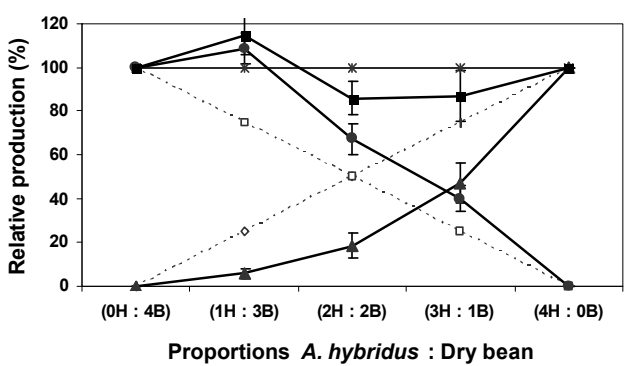

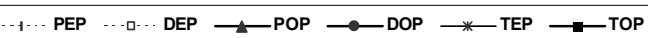

D

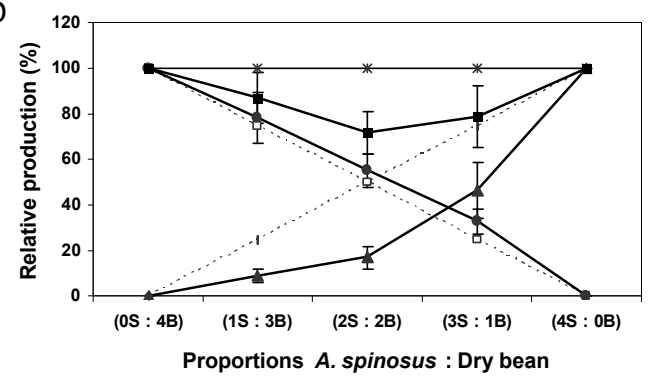

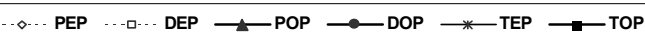

$\mathrm{F}$

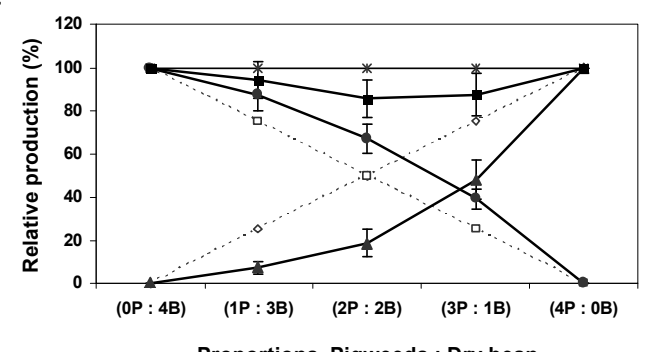

Proportions Pigweeds : Dry bean

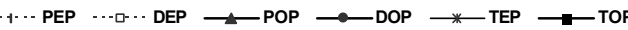

Figure 1 - Relative yield shoot biomass of pigweeds and dry bean plants as function of the different population proportions. A Amaranthus deflexus; B - A. hybridus; C - A. retroflexus; D - A. spinosus; E - A. viridis, F - Mean of all species. Piracicaba, $\mathrm{SP}, \mathrm{Brazil}, 2005$. $\mathrm{PEP}=$ pigweed expected production, $\mathrm{DEP}=$ dry bean expected production, $\mathrm{POP}=$ pigweed observed production, $\mathrm{DOP}=$ dry bean observed production, $\mathrm{TEP}=$ total expected production, $\mathrm{TOP}=$ total observed production.

dry-bean was interpreted as a superior competitor (Figure 1).

The largest competitive ability of the dry bean identified in this experiment may be consequence of several factors, mainly those related to the biological characteristics of the species. Some supposed advantages are: (i) the dry bean germination is epigeous, with big seedlings with well lifted cotyledons over the soil surface, which secures its competitive advantage; (ii) dry bean seedlings have large cotyledon leaves that shadow little seedling weeds, which is the case of the pigweeds; and (iii) the dry bean cycle contributes to the fast initial production of large leaves (trifoliate), mainly in the case of short-cycle cultivars as the one here used.
López-Ovejero (2006) also reported a condition where the crop was more competitive than the weed species. The competitive ability of crabgrass biotypes (Digitaria ciliaris) with the soybean crop (Glycine max) were compared using the replacement series design. Soybean was a better competitor than the crabgrass biotypes, with better yield than the expected production. Seven days of delay in the soybean emergence relative to the emergence of the crabgrass increased the crabgrass competitiveness, but it was not sufficient to invert the competitive situation.

There are still other characteristics related to field or experiment conduction that interfere on species competitiveness. The negative effects of competition on crop yield are commonly reduced with the 
increasing of the time interval between the crop and weed emergence (Fleck et al., 2004). In this case, weeds that emerge early before the crops are more able to compete than those of late emergence.

Using the replacement series design, Rizzardi et al. (2004) showed that the reduction in the mass of the soybean crop was more intense in the presence of Ipomoea ramosissima than of Euphorbia heterophylla and, mainly, in the situations in which the weeds were established before the crop. Rizzardi (2002) studied the relation between yield losses caused by late soybean seeding and the vegetal covering desiccation. Yield losses caused by the presence of 50 plants $\mathrm{m}^{-2}$ of Bidens spp. and Sida rhombifolia were less intense when the foliage was desiccated nearer soybean sowing.

The results obtained in this experiment and in the available literature indicate that, in many cases, the competitive ability of a crop is superior in relation to the competitive ability of the weeds, when compared in equivalent proportions (Passini et al., 2003; LópezOvejero, 2006; Christoffoleti \& Victoria Filho, 1996). Therefore, probably the high weed infestation density is an interespecific factor of competition that presents more negative effects over the agricultural production than the intrinsic competition ability of the species. For example, Aguyoh \& Masiunas (2003) observed that the increasing of $A$. retroflexus density promoted a reduction in the dry bean production, reaching losses sometimes greater than $50 \%$, for the highest densities. Similar results were obtained by Klingaman \& Oliver (1994), Dieleman et al. (1995) and Bensch et al. (2003) studying the soybean crop competition with weed species of the Amaranthus genus.

Dry bean plants are more competitive than each one of the five evaluated species of Amaranthus when grown in equivalent proportion; A. deflexus and $A$. viridis had their phenology less affected by the competition with dry bean; the intraspecific competition was the most damaging to dry bean plants, which suggests that the damages caused by the weeds are more related to the high density of infestation than to the intrinsic competitive ability of the species.

\section{ACKNOWLEDGEMENTS}

To FAPESP for a scholarship granted to the first author.

\section{REFERENCES}

AGUYOH, J.N.; MASIUNAS, J.B. Interference of redroot pigweed (Amaranthus retroflexus) with snap beans. Weed Science, v.51, p.202-207, 2003.

ANDERSON, R.L.; NIELSEN, D.C. Emergence pattern of five weeds in the Central Greal Plains. Weed Technology, v.10, p.744-749, 1996.
ARÉVALO, R.A.; ROZANSKI, A. Plantas daninhas na cultura do feijão. In: SEMINÁRIO SOBRE PRAGAS E DOENÇAS DO FEIJOEIRO, 4., Campinas, 1991, Campinas. Anais. Campinas: Estação Experimental do Instituto Biológico, 1991. p.33-43.

BENSCH, C.N.; HORAK, M.J.; PETERSON, D. Interference of redroot pigweed (Amaranthus retroflexus), Palmer amaranth (A. palmerii), and common waterhemp (A. rudis) in soybean. Weed Science, v.51, p.37-43, 2003.

CARVALHO, S.J.P. Características biológicas e suscetibilidade a herbicidas de cinco espécies de plantas daninhas do gênero Amaranthus. Piracicaba: USP/ESALQ, 2006. 96p. Dissertação (Mestrado).

CHRISTOFFOLETI, P.J. Growth, competitive ability, and fitness of sulfonylurea resistant and susceptible Kochia scoparia biotypes. Fort Collins: Colorado State University, 1992. 198p. (Ph.D. Thesis).

CHRISTOFFOLETI, P.J.; VICTORIA FILHO, R. Efeitos da densidade e proporção de plantas de milho (Zea mays L.) e caruru (Amaranthus retroflexus L.) em competição. Planta Daninha, v.14, p.42-47, 1996.

CHRISTOFFOLETI, P.J.; LÓPEZ-OVEJERO, R.F.; NICOLAI, M. Manejo racional de plantas daninhas na cultura do feijoeiro. In: FANCELLI, A.L.; DOURADO NETO, D. (Ed.) Feijão irrigado: tecnologia \& produção. Piracicaba: ESALQ/USP, 2005. p.29-42.

COBUCCI, T. Manejo e controle de plantas daninhas em feijão. In: VARGAS, L.; ROMAN, E.S. (Ed.) Manual de manejo e controle de plantas daninhas. Bento Gonçalves: Embrapa Uva e Vinho, 2004. p.453-480.

COUSENS, R. Aspects of the design and interpretation of competition (interference) experiments. Weed Technology, v.5, p.664-673, 1991.

DIELEMAN, A.; HAMILL, A.S.; WEISE, S.F.; SWANTON, C.J. Empirical models of pigweed (Amaranthus spp.) interference in soybean (Glycine max). Weed Science, v.43, p.612-618, 1995.

FLECK, N.G. Princípios do controle de plantas daninhas. Porto Alegre: UFRGS, 1992. 70p.

FLECK, N.G; RIZZARDI, M.A.; AGOSTINETTO, D.; BALBINOT JÚNIOR, A.A. Interferência de picão preto e guanxuma com a soja: efeitos da densidade de planta e época relativa de emergência. Ciência Rural, v.34, p.41-48, 2004.

HARPER, J.L. Mixtures of species. I. Space and proportions. In: HARPER. J.L. (Ed.) Population biology of plants. 8 ed. London: Academic Press, 1977. p.237-276.

HESS, M.; BARRALIS, G.; BLEIHOLDER, H.; BUHRS, L.; EGGERS, T.H.; HACK, H.; STAUSS, R. Use of the extendend $\mathrm{BBCH}$ escale: general for descriptions of the growth stages of mono-and dicotyledonous weed species. Weed Research, v.37, p.433-441, 1997.

ITULYA, F.M.; MWAJA, V.N.; MASIUNAS, J.B. Collard-cowpea intercrop response to nitrogen fertilization, redroot pigweed density, and collard harvest frequency. Hortscience, v.32, p.850853, 1997.

KISSMANN, K.G.; GROTH, D. Plantas infestantes e nocivas. 2. ed. São Paulo: BASF, 1999. v.2, 978p.

KLINGAMAN, T.E.; OLIVER, L.R. Palmer amaranth (Amaranthus palmerii) interference in soybean (Glycine max). Weed Science, v.42, p.523-527, 1994.

KOZLOWSKI, L.A.; RONZELLI JÚNIOR, P.; PURISSIMO, C.; DAROS, E.; KOEHLER, H.S. Período crítico de interferência das plantas daninhas na cultura do feijoeiro-comum em sistema de semeadura direta. Planta Daninha, v.20, p.213-220, 2002.

LÓPEZ-OVEJERO, R.F. Resistência de populações da planta daninha Digitaria ciliaris (Retz.) Koel. a herbicidas inibidores da acetil coenzima A carboxilase (ACCase). Piracicaba: USP/ESALQ, 2006. 101p. Tese (Doutorado).

McGILCHRIST, C.A.; TRENBATH, B.R. A revised analysis of plant competition experiments. Biometrics, v.27, p.659-671, 1971. 
PASSINI, T.; CHRISTOFFOLETI, P.J.; YADA, I.F.U. Competitivity of the common-bean plant relative to the weed alexandergrass [Brachiaria plantaginea (Link) Hitch.]. Scientia Agricola, v.60, p.259-268, 2003.

PITELLI, R.A.; PITELLI, R.L.C.M. Biologia e ecofisiologia das plantas daninhas. In: VARGAS, L.; ROMAN, E.S. (Ed.) Manual de manejo e controle de plantas daninhas. Bento Gonçalves: Embrapa Uva e Vinho, 2004. p.29-55.

RADOSEVICH, S.R. Methods to study interactions among crops and weeds. Weed Technology, v.1, p.190-198, 1987.

RADOSEVICH, S. Physiological aspects of competition. In: RADOSEVICH, S.; HOLT, J.S.; GHERSA, C. (Ed.) Weed ecology: implications for vegetation management. 2 ed. New York: John Willey, 1996. p.217-301.

RADOSEVICH, S.R.; ROUSH, M.L. The role of competition in agriculture. In: GRACE, J.B.; TILLMANN, D. (Ed.) Perspectives on plant competition. San Diego: Academic Press, 1990. p.341-363.

RICKLEFS, R. The economy of nature. New York: W.H. Freeman, 1997. 677p.

RIZZARDI, M.A. Nível de dano econômico para tomada de decisão no controle de picão-preto (Bidens spp.) e guanxuma (Sida rhombifolia L.) na cultura de soja. 2002. Porto Alegre: Universidade Federal do Rio Grande do Sul, 2002. Tese (Doutorado). 175p.
RIZZARDI, M.A.; ROMAN, E.S.; BOROWSKI, D.Z.; MARCON, R. Interfererência de populações de Euphorbia heterophylla e Ipomoea ramosissima isoladas ou em misturas sobre a cultura de soja. Planta Daninha, v.22, p.29-34, 2004.

ROHRIG, M.; STUTZEL, H. A model for light competition between vegetable crops and weed. European Journal of Agronomy, v.14, p.13-29, 2001.

ROUSH, M.L.; RADOSEVISH, S.; WAGNER, R.G.; MAXWELL, B.; PETERSON, T.D. A comparison of methods for measuring effects of density and proportion in plant competition experiments. Weed Science, v.37, p.268-275, 1989.

WIT, C.T.; van den BERG, J.P. Competition between herbage plants. Netherlands Journal of Agricultural Science, v.13, p.212$221,1965$.

Received October 11, 2006

Accepted November 08, 2007 